\title{
RESPONSIBLE COMPETITIVENESS FACTORS AND COMPETITIVE ADVANTAGE: A SOCIALLY RESPONSIBLE - HRM PERSPECTIVE
}

\author{
Elona ÇERA ${ }^{a *}$, Aleš GREGAR ${ }^{b}$, Jana MATOŠKOV $A^{c}$, Zuhair ABBAS ${ }^{d}$ \\ ${ }^{a, b, c, d}$ Tomas Bata University in Zlín, Czech Republic
}

\begin{abstract}
Over the past decade, the notion of sustainability has received increasing attention in both practice and research. The main goal of this study is to contribute to CSR and HRM research by developing a framework for Socially Responsible HRM (SR-HRM) practices and competitive adavantage throw responsible competitiveness factors. For the purpose of this study, an exhaustive literature review has been conducted with particular focus on high-quality journals with a proven influence in the $H R M$ filed. Concerning searching strategy are analysed forty-two papers published in $Q 1$ and $Q 2$ journal ranking (SJR), two reports published from Global Reporting Initiative (GRI) and Eurepean Commision, four books on the filed of HRM, and two papers published on Q3 journal ranking (SJR). The literature review results show that SR-HRM has become an important and irreversible component of doing business. Some SR-HMR practices such as: potential to attract and retain the most motivated employees; opportunities for continuous development and training; company's capacity to manage employee relationships and conflict resolution; the ability to communicate relevant information fluently, transparently, and foster productive dialogue; enhancement of diversity as a core value; remuneration policy; company justice system; sanitation and safety standards; and work-life balance, when properly implemented, enhance competitive advantage.
\end{abstract}

KEYWORDS: human resource management, corporate social responsibility, competitive advantage, responsible competitiveness

DOI: $10.24818 / \mathrm{IMC} / 2021 / 04.02$

\section{INTRODUCTION}

Human Resource Management (HRM) has evolved as a field during the last four decades (Armstrong 2012; Beer et al. 2015; Brewster, 2004; Shen, 2011; Voegtlin \& Greenwood, 2013). Analyses of such an evolution depict the alteration from a stage during which the physical management of staff/personnel was primarily dedicated to processing data (Morgeson et al. 2013) and performing an efficient process, to a stage where Human Resource plays a strategic role in organizational effectiveness, efficiency, and market advantage (firm success) (Brewster, 2004; Barrena Martinez et al. 2017; de Sousa Filho et al. 2010; Mintzberg, 1983). In conjunction with the business management sector, HRM has evolved throughout time in response to corporate objectives and needs (Brewster, 2004; Burke et al, 2006; Morgeson et al. 2013). Technical personnel have made significant contributions to the development and improvement of personnel management, such as the globalization of corporations and the development of legal workers (Gahlawat \& Kundu, 2018). One of the best representations of climate change for HRM operators is the inclusion of the concept corporate social responsibility (CSR) (Brewster, 2004; European Commission, 2011). For corporations, the value of shareholders and the standard of economic goals are no longer considered sufficient (Lechuga Sancho et al., 2018; McWilliams et al., 2006). In corporate management, society

\footnotetext{
*Corresponding author. E-mail address: e1cera@utb.cz
} 
expects honesty, openness, and ethical principles to be taken into account (Iamandi, 2011). Researchers at the World Health Organization focus on the potential benefits of measuring the ratio, although combining CSR with professional methods will increase the results of the framework (Global Reporting Initiative, 2011). In some jobs, variables have a light weight on positive growth, such as full image, credibility, distinction, and client loyalty that precede CSR actions. In addition, most of the studies scrutinized for the purpose of this study show that the starting point for CSR success is the positive aspect of the stakeholder generation, an aspect that contributes to the formation. In recent years, efforts have been made to propose. Among the most outstanding insights to socially responsible human resource policy and practise are highlighted in the literature study.A growing number of scholars (Aguilera et al. 2007; Eisenberger et al. 2016; Voegtlin \& Greenwood, 2013; Zadek, 2006) has focused on the potential benefits of CSR initiatives in internal areas such as HRM over the last decade. Companies with the idea of avoiding bad reputation in the area of social responsibility need to emphasize the need to visualize CSR activities (Martinez et al. 2011). Organizations such as the United Nations have established initiatives to comply with the principles of social responsibility contained in the United Nations Global Compact, the principles approved by the European Union (EU) in 2011 (European Commission, 2011), and sustainable CSR development strategies. These should be agreed upon by economic entities and implemented by them (European Commission, 2011). In particular, the CSR Strategy promoted by the European Union aims to provide social, ethical, and environmental value to three key groups, in line with the proposals presented in this article (Brewster, 1995; Brewster, 2004; European Commission, 2011; Iamandi, 2011; Ziek, 2009): (i) They are considered increasingly important to competitiveness due to significant savings in cost, capital access, customer relationships, HRM, and innovation. (ii) The EU economy contributes to a more sustainable economy by increasing the sustainability and innovation of businesses (European Commission, 2011; Apospori et al. 2008). (iii) Society promotes a set of values that can create a more collaborative environment. Recruitment and selection policies have a significant impact on the human resources function's strategy and outcomes (Buller \& McEvoy, 2012; Iamandi, 2011; Kramar, 2014). As a result of the increased market competitiveness to attract and retain higherqualified employees. This notion aims to highlight how businesses that place a premium on acquiring highly qualified employees can achieve a competitive advantage through human capital (Porter \& Kramer, 2006; Zadek, 2006). Additionally, the definition of a socially responsible human resource policy structure can lead to the establishment of new frameworks that are useful for businesses and scholars (Barrena Martinez et al. 2017; Lechuga Sancho et al. 2018; Shen \& Zhang, 2017). It is also concerned with highlighting the strengths and weaknesses that facilitate or limit the inclusion of CSR into HRM (Shen \& Zhu, 2011), and the potential implications of these policies in the process are social, financial, and intangible (Barrena Martinez et al. 2017). As a result, it is possible to demonstrate how responsible HRM policies and practises may be turned into strategic edge, and to examine how environmental and other predictor variable influence this connection. There are many existing studies which analyze SR-HRM practices and their influence on competitive advantage. However, in-depth and broader studies on this field are still needed, to better understand what is its role firm management strategy, and which are the factors/practices that provide firms with competitive edges. This study contributes to this gap on summarizing some of the most important findings about the concept of SR-HRM and responsible competitiveness as an instrument that enables firms to gain competitiveness with an employee-centered strategy.

\section{LITERATURE REVIEW}

\subsection{Socially responsible human resources management}

To foster an intelligible system that allows for a clearer representation of the CSR orientation in HRM, the establishment of a logical point of view should be utilized. The worth of the relevant 
worldview understands the importance of the distinctions among conditions, which fundamentally impact HRM as shaped by organizations (European Commission, 2011). The improvement of this hypothetical point of view has been enormously impacted by the commitments of several authors (European Commission, 2011), in the light of the scientific arrangements and the examination of factors like culture, enactment and implementation, tenure, employee organizational inclusion (EOI) and consultative plans and practices that may influence the HRM work (Barrena Martinez et al. 2017; Hemphill, 2004). This methodology has been analyzed and put into practice through a global HRM project (Global Reporting Initiative, 2011), The Cranfield Organization (CRANET), which included an enormous number of European nations (Barrena Martinez et al. 2017; Martinez et al. 2011). The CRANET examines similar execution in HRM inside Europe, but also internationally (Global Reporting Initiative, 2011). The examinations distributed from the CRANET test feature two factors as the most applicable logical angles that influence employee commitment to organizational performance:

I. The public setting: the authoritative, legitimate, social, financial and world of politics, work market, provincial or sectorial attributes, etc; and

II. The worldwide (internation) setting: qualities coming about because of globalization, key collusions and control of auxiliaries by multinationals, among others.

These context-oriented factors altogether outline how HR is overseen, bringing about a proposition of two separated HRM models (Apospori et al. 2008; Global Reporting Initiative, 2011; Shen et al. 2009), developed by western societies: a) the US model; and b) the European model. Zeroing in on Europe, the proposition expresses that there are critical primary and institutional contrasts that help diverse HRM rehearses in Central and Eastern Europe, as opposed to Western Europe (Apospori et al. 2008; Barrena Martinez et al. 2017). The theoretical proposition of a SR-HRM framework in this paper depends on the thoughts of HRM from the European mainland, and especially Western Europe. The significant contrast between HRM practices in the US and in Western Europe depends on how much HRM is impacted and controlled by state guidelines (Apospori et al. 2008; Global Reporting Initiative, 2011; Martinez et al. 2011), featuring three primary viewpoints that influence this structure: the level of business insurance; administrative necessities with regards to pay and long stretches of work, and enactment on types of business contract (Barrena Martinez et al. 2017). Another vital context-oriented variable that influences the European HRM system at a greater pace than in the US is the impact of worker's organizations/unions in Western European societies, owing to a larger political divide between the two contexts (Apospori et al. 2008). Several European societies put greater emphasis on the social wellbeing of employees, in the context of more leftleaning policy-making processes (Apospori et al. 2008; Barrena Martinez et al. 2017). As to, in the light of the fact that it is characterized as an interaction set up for incorporating social, innate, and moral basic freedoms and buyer worries into an organization's business activities and central procedures in close collaboration with their partners; it becomes clear that state guidelines will characterize the beginning stage of the association's level of participation in the presentation of CSR into their business methodologies. CSR will start when organizations have finished the exercises they need to do to work lawfully. Moreover, state regulations and guidelines differently affect several European nations (European Commission, 2011; Apospori et al. 2008). Therefore, the impact of the legal and external CSR regulations has a decisive impact on the modeling of human resources management (Macke \& Genari 2019; Shen et al. 2009). Based on the Harvard model (Porter \& Kramer, 2006), not only shareholders, but also a wide range of stakeholders such as employees, unions, managers, communities, governments, and situational factors have the potential to affect human resource management (social value, labor market, business situation, etc.) (Castelo \& Rodrigues 2006; Donaldson \& Preston, 1995). Previous management decisions and history, characteristics of the workforce, company task technology, management philosophy and business strategy also play a role (Blowfield \& Murray 2011; Sasse \& Trahan, 2007; Zadek, 2006). Paying attention to all of these aspects leads to higher economic value (organizational effectiveness) 
(Husted \& Salazar, 2006), personal well-being (Shao et al. 2019), and social acceptance (Zhao et al. 2019). Consistent with this policy, some authors (Husted, 2003; Husted \& Salazar, 2006; Zadek, 2006) pay particular attention to the positive and negative impacts that human resource activities can have on a variety of stakeholders by organizations that exceed their financial performance targets. Moreover, it should be emphasized that, in order to avoid a bad reputation in the area of social responsibility, companies must make their CSR activities visible (Aguilera et al. 2007; Porter \& Kramer, 2006). Institutions such as the United Nations have entered into agreements with economic agents to develop initiatives to promote compliance with the principles of social responsibility of the United Nations Global Compact (Global Reporting Initiative, 2011), recognized by the European Union (EU) in 2011 (European Commission, 2011), and to promote sustainable development and a well-devised CSR development strategy. In particular, in line with the proposals presented in this document, the CSR strategies promoted by the European Union aim to provide social, ethical and environmental value to three important groups:

I. companies, as the inclusion of CSR in their actions for their competitiveness is seen as an increasingly important asset that offers important advantages in terms of risk management, reduction in costs, access to finance, consumer connections, human resource management, and innovations;

II. the EU economy, which makes businesses more resilient and innovative, which contributes to a more sustainable economy; and

III. a society that promotes a set of values upon which a more coherent collaborative environment can be built.

In order for companies to implement CSR, international and European companies often apply two important international CSR standards: the Global Reporting Initiative (GRI) and ISO 26000 (Barrena Martinez et al. 2017; Global Reporting Initiative, 2011; Lechuga Sancho et al. 2018). Both standards provide guidelines for developing and disseminating the social aspects of their activities through their reports. In addition, the structure of their personnel management and the adaptation to a larger number of SR-HR guidelines are influenced.

\subsection{Responsible comeptitiveness factors: sr-hrm prespective}

Social responsibility human resource policy has been proposed to introduce social approaches to improve the personal and organizational level of employer-employee relationships, taking into account the research of some scholars and the perspectives of the above institutions (BornayBarrachina et al., 2012). The first practise seeks to encapsulate the core of this policy by including attempts to establish a decent workplace that honors employees' human rights, ethics, social responsibility, and rights (Shao et al. 2019). This process ensures a working environment where employees can work comfortably and perform tasks efficiently (Shao et al., 2019; Shen, 2011). In addition, given the importance of trade unions in the relationship between employers and employees, workers with information about the company can facilitate access to the workers' union representatives with advisory worker representatives (Brewster, 1995; Iamandi, 2011; Halme et al. 2009). It might also be considered as a secondary practise. Many writers (Brewster, 2004; BornayBarrachina et al., 2012) claim that organisations' voluntary attempts to foster communication between employees and trade unions result in fewer labour conflicts, lower absenteeism, and greater trust in the company, among other things. Some other technique that supports socially responsible management of employer-employee interactions, according to Bornay-Barrachina et al. (2012), is the distribution of messages regarding organisational changes to workers, as well as notifications which may influence legal ties. Employees may better plan their long-term career and growth in the firm with this strategy. 


\subsection{From responsible competititveness practices to competitive advantage}

A socially responsible human resource policy is defined (Shao et al., 2019; Shen, 2011; Barrena Martinez et al., 2017; European Commission, 2011) as a policy that companies voluntarily integrate into their human resource management area with the dual objective of:

1. Ethical, social, work-related and humane values of their employees. To meet the concerns and promote the satisfaction of its employees and proper development in the company; and

2. Adding value to businesses in terms of their human capital.

A review of studies (Luu, 2020; Shao et al., 2019; Barrena Martinez et al., 2017; Shen \& Zhang, 2017) highlights some of the similarities in proposing policies and practices for socially responsible human resources. Most authors work under international or European standards, such as the European Commission, the GRI, or the tripartite declaration of the principles of the International Labor Organization's multinational enterprises (Martinez et al. 2011; Barrena Martinez et al. 2017; Lechuga Sancho et al. 2018; Macke \& Genari, 2018). Reviews of these studies find common ground in terms of social responsibilities such as training and development (Aguinis \& Kraiger, 2009), communication (Ziek, 2009), compensation (Ehnert et al. 2014; Husted \& Salazar, 2006), workplace health and safety (Barrena Martinez et al. 2017), employment relationships (Voegtlin \& Greenwood, 2013), diversity and equal opportunity (Shen, 2011; Shen et al. 2009; Zhao et al. 2019). Although HRM capabilities evolve and refine the way human capital is managed, the reasons for these similarities are always taken into account when trying to better understand employee performance and organizational outcomes. There are other important areas as well. Many authors (Wang et al. 2015; Barrena Martinez et al. 2017; Luu 2021) have found several strategic HRM areas in international research in European countries. Social responsibility has become a strong and irreversible part of doing business (Mintzberg, 1983; Barney, 1991; Blowfield \& Murray, 2011). If managed effectively, CSR programs and projects can generate significant benefits in terms of employee motivation and loyalty, as well as in terms of credibility and return (Buller \& McEvoy, 2012; Burke \& Logson, 1996; Lechuga Sancho et al. 2018). CSR can also help strengthen valuable partnerships. Strategy researchers (Buller \& McEvoy, 2012; Porter \& Kramer, 2006; Kramar, 2014) see credibility as an internal resource that should be well-managed because it is a potential source of significant privilege and competitive advantage.

\section{METHODOLOGY}

For the purpose of this study, an exhaustive literature review has been conducted with particular focus on the relationship between HRM and CSR, and how the resulting Socially Responsible Human Resource Management (SR-HRM) affects Competitive Advantage (CA). Special emphasis was put on mostly on relevant literature published from 2010 to 2021, especially publications focusing on companies established and operating in Europe and North America. The list of analysed papers is mainly focued on peer-reviewed journals (reference Scimago Journal \& Country Rank) specially targeted on HRM area. Concerning searching strategy are analysed 42 papers published in Q1 and Q2 journal ranking (SJR), 2 reports published from Global Reporting Initiative (GRI) and Eurepean Commision, 4 books on the filed of HRM and 2 papers published on Q3 journal ranking (SJR). We analyzed the abstracts and keywords within the selected journals using the following key terms: "HRM, SR-HRM, CSR, Competitive Advantage and Responsible Competitiveness".

\section{RESULTS}

International, transnational, and European companies often apply two major international CSR standards for companies to implement CSR: Global Reporting Initiative (GRI) and ISO 26000. it was found that the best framework for the effective implementation of SR-HRM methodologies would be based on practice analysis from literature review, which can further divide into two phases: (i) Identification of the best companies listed on the stock market index - A review of the 
literature using the analysis of CSR reports. To select possible SR-HR policies and practices for the best companies and CSR standards (GRI and ISO 26000) that can create SR-HRM configurations.

And, secondly (ii) approval by a group of experts to reach a consensus on the contents of these policies and procedures. In addition to proposing the framework described above, an analysis of the data yielded by literature review, brought to light a new perspective on CA - Responsible Competitiveness (RC). Hence, factors contributing to the $\mathrm{CR}$ perspective of CA were further examined, including: the potential to attract and retain the most motivated employees; opportunities for continuous development and training; company's capacity to manage employee relationships and conflict resolution; the ability to communicate relevant information fluently, transparently, and foster productive dialogue; enhancement of diversity as a core value; remuneration policy; company justice system; sanitation and safety standards; and work-life balance. Social responsibility has become an important and irreversible component of doing business (Barney, 1991; Blowfield \& Murray, 2011; Mintzberg, 1983). CSR programs and projects, when managed properly, can yield significant benefits in terms of employee motivation and loyalty, as well as credibility and return on investment (Buller \& McEvoy, 2012; Burke \& Logson, 1996; Lechuga Sancho et al. 2018). The studies have found that SR-HRM strategies/practices, when properly implemented, can create a competitive advantage and suggest that there is a positive correlation between social responsibility HRM policies and competitive advantage.

\section{DISCUSSION, CONCLUSIONS AND LIMITATIONS}

Despite the availability of some studies on the relationship between HRM and CSR, which may set the basis for future research, this area of study remains the need for further development. To do so, the SR-HRM model used a contextual perspective as a baseline, identifying the importance of national and international elements. This theory generating process emphasizes the necessity to manage human resources in a socially responsible manner in order to fulfill emerging socioeconomic problems. In addition, the definition of socially responsible policies and strategic goals as well as their formulation in the practice of multiple human resources has been provided in this study. Regarding the advantages of the proposal from a professional point of view, many scholars (Barrena Martinez et al. 2017; Buller \& McEvoy, 2012; Halme et al. 2009; Iamandi, 2011; Shen, 2011) also attributed the relative weight to the methods that define different policies. This result is a valuable contribution as it is difficult to consider CSR practices in the context of the process of creating CSR indices in HRM, which paves the way for the future for academics and professionals in the search for synergy between the two areas of HRM (Iamandi, 2011; Buller \& McEvoy, 2012). Furthermore, determining the alignment of socially responsible human resource policies can help establish a new framework useful for companies and academics. The potential consequences of these policies in terms of economic, financial and intangible consequences are also relevant by examining the process, highlighting the strengths and types of vulnerabilities that promote or limit the integration of CSR into HRM (Husted \& Salazar, 2006; Iamandi, 2011; Shen, 201).

Furthermore, SR-HRM rules and practices analyzed were mostly developed by panels/teams of researchers composed of academic experts mostly from a European perspective (context) (Apospori et al. 2008; Brewster,2004; Halme et al. 2009; Lechuga Sancho et al. 2018; Martinez et al. 2011). There could be a bias impact as a result of this. As a result, evidence of a possible SR-HRM arrangement, which may differ conceptually and practically from current situations, are likely to supplant them (Barrena Martinez et al. 2017). Finally, our study has certain limitations. The theoretical underpinning of the SR-HRM, competitive advantage relationship is quite noticeable, as noted in the literature review. However, there is still room to investigate additional theories to explain this relationship. Furthermore, the studies are mostly focus on US or Europe, thus, can provide configuration of SR-HRM, which possibly differs in conceptual and practical terms from other contexts (Barrena Martinez et al. 2017). Moreover, regarding the methodology, would be beneficial to in large the sample of analyzed papers, and to have a broader view of this phenomenon. 


\section{ACKNOWLEDGMENT}

The authors are thankful to the Internal Grant Agency of FaME-TBU project No. IGA/FaME/2021/009, with the following title "Green Human Resource Management Practices Leading Transformation towards Sustainable Performance in the Selected Sectors" and the second project No. IGA/FaME/2021/008, with the following title Sustainability of Human Resources Management", for providing financial support to carrying out this research.

\section{REFERENCES}

Aguilera, R. V., Rupp, D. E., Williams, C. A., \& Ganapathi, J. (2007). Putting the S back in corporate social responsibility: A multilevel theory of social change in organizations. Academy of management review, 32(3), 836-863.

Aguinis, H., \& Kraiger, K. (2009). Benefits of training and development for individuals and teams, organizations, and society. Annual review of psychology, 60, 451-474.

Apospori, E., Nikandrou, I., Brewster, C., \& Papalexandris, N. (2008). HRM and organizational performance in northern and southern Europe. The International Journal of Human Resource Management, 19, 1187-1207.

Armstrong, M. (2012). Armstrong's handbook of human resource management practice. London: Kogan Page.

Barney, J. (1991). Firm resources and sustained competitive advantage. Journal of Management, 17(1), 99-120.

Barrena-Martínez, J., López-Fernández, M., \& Romero-Fernández, P. M. (2017). Socially responsible human resource policies and practices: Academic and professional validation. European research on management and business economics, 23(1), 55-61.

Beer, M., Boselie, P., \& Brewster, C. (2015). Back to the future: Implications for the field of HRM of the multistakeholder perspective proposed 30 years ago. Human Resource Management, 54, 427-438.

Blowfield, M., \& Murray, A. (2011). Corporate responsibility. Oxford: Oxford University Press.

Bornay-Barrachina, M., De la Rosa-Navarro, D., López-Cabrales, A., \& Valle-Cabrera, R. (2012). Employment relationships and firm innovation: the double role of human capital. British Journal of Management, 23(2), 223-240.

Brewster, C. (1995). Towards a 'European model of human resource management. Journal of International Business Studies, 26, 1-21.

Brewster, C. (2004). European perspectives on human resource management. Human Resource Management Review, 14, 365-382.

Buller, P. F., \& McEvoy, G. M. (2012). Strategy, human resource management and performance: Sharpening line of sight. Human Resource Management Review, 22, 43-56.

Burke, L., \& Logsdon, J. M. (1996). How corporate social responsibility pays off. Long Range Planning, 29(4), 495-502.

Burke, R. J., \& Cooper, C. L. (Eds.). (2006). Reinventing HRM: Challenges and new directions. Routledge.

Castelo B., M., \& Rodrigues, L. L. (2006). Corporate social responsibility and resource-based perspectives. Journal of Business Ethics, 69(2), 111-132.

Donaldson, T., \& Preston, L. (1995). The stakeholder theory of the corporation: concepts, evidence and implications. Academy of Management Review, 20(1), 65-91.

Ehnert, I. (2014). Sustainability and Human Resource Management Developing Sustainable Business Organizations. Springer. 
European Commission. (2011). Corporate social responsibility: A new definition, a new agenda for action (MEMO/11/730 Brussels). Retrieved October 25, 2011, from http://europa.eu/ rapid/press-release_MEMO-11-730_en.htm

Gahlawat, N., \& Kundu, S. C. (2018). Exploring the connection between socially responsible HRM and citizenship behavior of employees in Indian context. Journal of Indian Business Research.

Global Reporting Initiative. (2011). GRI and ISO 26000: How to use the GRI Guidelines in combination with ISO 26000. Retrieved from https://www.globalreporting.org/ resourcelibrary/How-To-Use-the-GRI-Guidelines-In-Conjunction-With-ISO26000.pdf

Greening, D. W., \& Turban, D. B. (2000). Corporate social performance as a competitive advantage in attracting a quality workforce. Business and Society, 39, 254-280.

Halme, M., Roome, N., \& Dobers, P. (2009). Corporate responsibility: reflections on context and consequences. Scandinavian Journal of Management, 25(1), 1-9.

Hemphill, T. A. (2004). Corporate citizenship: the case for a new corporate governance model. Business \& Society, 109(3), 339-361.

Husted, B. W. (2003). Governance choices for corporate social responsibility: to contribute, collaborate or internalize? Long Range Planning, 36(5), 481-498.

Husted, B. W., \& Salazar, J. J. (2006). Taking Friedman seriously: maximizing profits and social performance. Journal of Management Studies, 43(1), 75-91.

Iamandi, I. (2011). Strategic approach of corporate social responsibility key drivers for increasing competitiveness at the European level. Economic Review, 3, 180-187.

Jiang, Z., Hu, X., \& Wang, Z. (2016). Employee-oriented HRM and voice behavior: A moderated mediation model. In Academy of Management Proceedings (Vol. 2016, No. 1, p. 10731). Briarcliff Manor, NY 10510: Academy of Management.

Kim, K. Y., Eisenberger, R., \& Baik, K. (2016). Perceived organizational support and affective organizational commitment: Moderating influence of perceived organizational competence. Journal of Organizational Behavior, 37(4), 558-583.

Kramar, R. (2014). Beyond strategic human resource management: Is sustainable human resource management the next approach?. The International Journal of Human Resource Management, $25,1069-1089$.

Logsdon, J. M., \& Wood, D. J. (2002). Reputation as an emerging construct in the business and society field: an introduction. Business and Society, 41(4), 365-370.

Luu, T. T. (2021). Socially responsible human resource practices and hospitality employee outcomes. International Journal of Contemporary Hospitality Management.

Macke, J., \& Genari, D. (2019). Systematic literature review on sustainable human resource management. Journal of cleaner production, 208, 806-815.

Martinez, J., Fernandez, M., \& Fernandez, P. (2011). Research proposal on the relationship between corporate social responsibility and strategic human resource management. International Journal of Management and Enterprise Development, 10, 173-187.

McWilliams, A., Siegel, D. S., \& Wright, P. M. (2006). Corporate social responsibility: strategic implications. Journal of Management Studies, 43(1), 1-18.

Mintzberg, H. (1983). The case for corporate social responsibility. Journal of Business Strategy, 4(2), 3-15.

Morgeson, F. P., Aguinis, H., Waldman, D. A., \& Siegel, D. S. (2013). Extending corporate social responsibility research to the human resource management and organizational behavior domains: A look to the future. Personnel Psychology, 66, 805-824.

Porter, M. E., \& Kramer, M. (2006). Strategy and society: the link between competitive advantage and corporate social responsibility. Harvard Business Review, 78-92. 
Sancho, M. P. L., Martínez-Martínez, D., Jorge, M. L., \& Madueño, J. H. (2018). Understanding the link between socially responsible human resource management and competitive performance in SMEs. Personnel Review.

Sasse, C. M., \& Trahan, R. T. (2007). Rethinking the new corporate philanthropy. Business Horizons, 50(1), 29-38.

Shao, D., Zhou, E., \& Gao, P. (2019). Influence of perceived socially responsible human resource management on task performance and social performance. Sustainability, 11(11), 3195.Shao et al. (2019).

Shen, J., Chanda, A., D’Netto, B., \& Monga, M. (2009). Managing diversity through human resource management: An international perspective and conceptual framework. The International Journal of Human Resource Management, 20, 235-251.

Shen, J. (2011). Developing the concept of socially responsible international human resource management. The International Journal of human resource management, 22(06), 1351-1363.

Shen, J., \& Jiuhua Zhu, C. (2011). Effects of socially responsible human resource management on employee organizational commitment. The International Journal of Human Resource Management, 22(15), 3020-3035.

Shen, J., \& Zhang, H. (2019). Socially responsible human resource management and employee support for external CSR: roles of organizational CSR climate and perceived CSR directed toward employees. Journal of Business Ethics, 156(3), 875-888.

Sousa Filho, J. M. D., Wanderley, L. S. O., Gómez, C. P., \& Farache, F. (2010). Strategic corporate social responsibility management for competitive advantage. BAR-Brazilian Administration Review, 7(3), 294-309.

Voegtlin, C., \& Greenwood, M. (2013). CSR and HRM: A review and conceptual analysis. Academy of Management. Proceedings, 2013(1):n/a.

Wang, S., Huang, W., Gao, Y., Ansett, S., \& Xu, S. (2015). Can socially responsible leaders drive Chinese firm performance? Leadership \& Organization Development Journal.

Zadek, S. (2006). Corporate responsibility and competitiveness at the macro level: responsible competitiveness: reshaping global markets through responsible business practices. Corporate Governance, 6(4), 334-348.

Zhao, H., Zhou, Q., He, P., \& Jiang, C. (2019). How and when does socially responsible HRM affect employees' organizational citizenship behaviors toward the environment? Journal of Business Ethics, 1-15.

Ziek, P. (2009). Making sense of CSR communication. Corporate Social Responsibility and Environmental Management, 16, 137-145. 